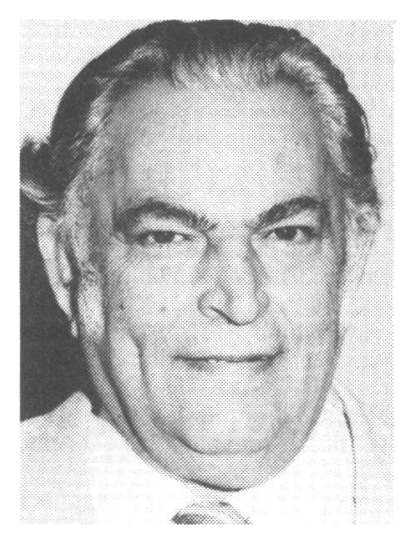

T. Khosla

\section{AGE, HEIGHT AND WEIGHT OF FEMALE OLYMPIC FINALISTS IN RUNNING EVENTS}

\author{
T. KHOSLA, PhD
}

Dept. of Medical Computing and Statistics, University of Wales College of Medicine, Heath Park, Cardiff CF4 4XN

\title{
ABSTRACT
}

Age, height, weight and body mass index (weight/height ${ }^{2}$ ) of women finalists from seven running events (100 $\mathrm{m}, 200 \mathrm{~m}$, $400 \mathrm{~m}, 800 \mathrm{~m}, 1500 \mathrm{~m}, 3000 \mathrm{~m}$ and marathon) are analysed. The data on 174 runners are derived from four Olympics (Munich, Montreal, Moscow and Los Angeles). On average endurance runners ( $3000 \mathrm{~m}$ and marathon are 4.8 years older, $6 \mathrm{~cm}$ shorter and $5 \mathrm{~kg}$ lighter for their height than sprinters $(200 \mathrm{~m}$ and $400 \mathrm{~m})$. A consistent trend of decreasing body mass index with run was observed; adjusting for height the marathon runners were $7 \mathrm{~kg}$ lighter than $100 \mathrm{~m}$ sprinters.

\section{INTRODUCTION}

Optimum requirements on age, height and body mass index have been reported previously on eight Olympic running events for men: $100 \mathrm{~m}, 2100 \mathrm{~m}, 400 \mathrm{~m}, 800 \mathrm{~m}, 1500 \mathrm{~m}$, $500 \mathrm{~m}$, and marathon (Khosla, 1978). That study was based on the Olympic finalists and non-finalists of Munich, 1972. Appreciable differences in some of the measured characteristics were observed between the finalists and nonfinalists within each event, and between the finalists of different events. A similar study on women runners is of interest, but until 1980 only short and medium distance running events $100 \mathrm{~m}, 200 \mathrm{~m}, 400 \mathrm{~m}, 800 \mathrm{~m}$ and $1500 \mathrm{~m}$ were held for them. The recent introduction of two long distance events ( $3000 \mathrm{~m}$ and marathon) at Los Angeles in 1984 now offers the opportunity of a comparative study.

The present investigation is confined to the finalists from each event, as their physical characteristics have been found to be appreciably different from non-finalists in several other events (Khosla, 1984). Physique is related to performance in specific sporting activities. Optimum standards based on the subgroup of finalists are of interest to research workers in sports physiology, and they are of course of value to the potential finalists of the future.

\section{DATA AND METHODS}

The subgroup of finalists was composed of those contestants who appeared in the finals after surviving the heats. The data on age, height and weight were extracted from three sources. Khosla and McBroom (1984) published the physical characteristics of female Olympic finalists from Munich, 1972 and Montreal, 1976. The unpublished material from Moscow, 1980 was kindly provided by the British Amateur Athletic Board (Personal Communication, 1985). The results on the finalists from Los Angeles, 1984 were reported by Simmons (1984).

Because height and weight are highly correlated, comparisons of body weight require adjustment for height. Body mass index (Weight/Height ${ }^{2}$ ) was used for this purpose. Adjusted weight in kilograms (at a height of $165 \mathrm{~cm}$ ) is much easier to interpret directly: adjusted weight $(\mathrm{kg})$ $=$ adjusted $=$ mass index $\times(165 \mathrm{~cm})^{2}$. Caution is necessary, however, in interpretiong the adjusted weight as it does not account for frame size. Moreover obesity and extra weight are often dissimilar. Extra weight may be muscle in a sprinter but adipose tissue in a more typical person. The adjusted weight on its own cannot distinguish between these possibilities.

The heights of women aged 18-34 in Great Britain are used as a reference population: mean 161.5, S.D. $6.1 \mathrm{~cm}$ (Knight, 1984). For Asian, African and Latin American countries the mean height is expected to be much lower (approximately $152 \mathrm{~cm}$ ).

Statistical analysis was done with the SPSSx computer program: one way analysis of variance incorporating Duncan's multiple range test at a significance level of $5 \%$ ( $p<$ 0.05). This procedure involves sequentially ordering the mean values for the groups of runners in the seven events. A total of 21, paired comparisons can thus be made. Pairwise multiple range tests take account of both the distance between a pair of means and the sample sizes on which they are based.

\section{RESULTS}

The table gives the mean and standard deviation of age, height, weight, body mass index and adjusted weight of finalists in seven running events. The three figures depict the scatter diagrams of age (Fig. 1), height (Fig. 2) and adjusted weight or body mass index (Fig. 3) for the events.

\section{Age}

The mean ages ranged from 22.9 years in $\mathbf{4 0 0} \mathrm{m}$ run to $\mathbf{2 9 . 0}$ years in marathon. The analysis of variance (Anova) revealed a highly significant result $(p<0.0001)$. The procedure of pairwise multiple comparisons showed that 11 of the 21 pairs were significantly different; (i) each mean of $100 \mathrm{~m}, 200 \mathrm{~m}$, and $400 \mathrm{~m}$ was significantly lower than each of $1500 \mathrm{~m}, 3000 \mathrm{~m}$ and marathon (9 comparisons) and (ii) $800 \mathrm{~m}$ was significantly lower than $1500 \mathrm{~m}$ and marathon (2 comparisons). Ages of individual runners ranged from 16.4 years in $400 \mathrm{~m}$ to 39 years in $1500 \mathrm{~m}$ and marathon (Fig. 1).

\section{Height}

The mean heights of runners ranged from $162.2 \mathrm{~cm}$ (63.9 in) in $3000 \mathrm{~m}$ to $170.5 \mathrm{~m}$ (67.1 in) in $200 \mathrm{~m}$ ('p' value from Anova $<0.0006$ ). The following 8 pairs of differences on means were significant: (i) $3000 \mathrm{~m}$ shorter than each of $100 \mathrm{~m}$, 
$200 \mathrm{~m}, 400 \mathrm{~m}, 800 \mathrm{~m}$, and $1500 \mathrm{~m}$ (5 pairs) (ii) $100 \mathrm{~m}$ shorter than each of $200 \mathrm{~m}$ and $400 \mathrm{~m}$ (2 pairs) and (iii) $800 \mathrm{~m}$ shorter than $200 \mathrm{~m}$ (1 pair). The heights of individual runners ranged from $154 \mathrm{~cm}(60.6 \mathrm{in})$ in $3000 \mathrm{~m}$ to $180 \mathrm{~cm}$ (171 in) in $100 \mathrm{~m}, 200 \mathrm{~m}$ and $800 \mathrm{~m}$ (Fig. 2). The horizontal line shows the average height of women in Great Britain.

TABLE I

Mean and standard deviation of age, height, weight, body mass index (weight 21000 ) and adjusted woight of female Olympic finalists in seven height

\begin{tabular}{|c|c|c|c|c|c|c|}
\hline Event & Number & $\begin{array}{l}\text { Age } \\
\text { years } \\
\text { mean } \\
\text { (S.D.) }\end{array}$ & $\begin{array}{l}\text { Height } \\
\text { cm } \\
\text { mean } \\
\text { (S.D.) }\end{array}$ & $\begin{array}{l}\text { woight } \\
\text { g/cm² } \\
\text { mean } \\
\text { (S.D.) }\end{array}$ & $\begin{array}{c}\text { Body } \\
\text { Mass } \\
\text { index } \\
165 \mathrm{~cm} \\
\text { mean } \\
\text { (S.D.) }\end{array}$ & $\begin{array}{c}\text { Adjusted } \\
\text { Weight } \\
\mathrm{kg} \text { at } \\
\text { mean } \\
\text { (S.D.) }\end{array}$ \\
\hline $100 \mathrm{~m}$ & 31 & $\begin{array}{l}23.0 \\
(2.75)\end{array}$ & $\begin{array}{c}166.7 \\
(5.56)\end{array}$ & $\begin{array}{l}58.0 \\
(5.74)\end{array}$ & $\begin{array}{c}2.086 \\
(0.170)\end{array}$ & $\begin{array}{l}56.8 \\
(4.64)\end{array}$ \\
\hline $200 \mathrm{~m}$ & 31 & $\begin{array}{l}23.2 \\
(2.58)\end{array}$ & $\begin{array}{c}170.5 \\
(5.20)\end{array}$ & $\begin{array}{l}59.2 \\
(5.22)\end{array}$ & $\begin{array}{c}2.035 \\
(0.153)\end{array}$ & $\begin{array}{l}55.4 \\
(4.17)\end{array}$ \\
\hline $400 \mathrm{~m}$ & 31 & $\begin{array}{l}22.9 \\
(3.54)\end{array}$ & $\begin{array}{r}169.5 \\
(4.45)\end{array}$ & $\begin{array}{l}57.9 \\
(5.39)\end{array}$ & $\begin{array}{c}2.013 \\
(0.155)\end{array}$ & $\begin{array}{l}54.8 \\
(4.23)\end{array}$ \\
\hline $800 \mathrm{~m}$ & 32 & $\begin{array}{l}24.5 \\
(3.12)\end{array}$ & $\begin{array}{r}167.4 \\
(4.57)\end{array}$ & $\begin{array}{l}55.5 \\
(4.22)\end{array}$ & $\begin{array}{c}1.979 \\
(0.121)\end{array}$ & $\begin{array}{l}53.9 \\
(3.29)\end{array}$ \\
\hline $1500 \mathrm{~m}$ & 34 & $\begin{array}{l}25.7 \\
(4.07)\end{array}$ & $\begin{array}{c}168.0 \\
(4.93)\end{array}$ & $\begin{array}{l}53.5 \\
(4.84)\end{array}$ & $\begin{array}{c}1.894 \\
(0.116)\end{array}$ & $\begin{array}{l}51.6 \\
(3.17)\end{array}$ \\
\hline $3000 \mathrm{~m}$ & 8 & $\begin{array}{l}26.5 \\
(5.01)\end{array}$ & $\begin{array}{c}162.2 \\
(5.70)\end{array}$ & $\begin{array}{l}48.8 \\
(3.84)\end{array}$ & $\begin{array}{c}1.858 \\
(0.167)\end{array}$ & $\begin{array}{l}50.5 \\
(4.55)\end{array}$ \\
\hline Marathon & 7 & $\begin{array}{l}29.0 \\
(4.83)\end{array}$ & $\begin{array}{r}165.9 \\
(5.87)\end{array}$ & $\begin{array}{l}50.2 \\
(3.21)\end{array}$ & $\begin{array}{c}1.826 \\
(0.099)\end{array}$ & $\begin{array}{l}49.7 \\
(2.70)\end{array}$ \\
\hline Total & 174 & $\begin{array}{l}24.5 \\
(3.81)\end{array}$ & $\begin{array}{c}168.0 \\
(5.29)\end{array}$ & $\begin{array}{l}56.1 \\
(5.63)\end{array}$ & $\begin{array}{c}1.986 \\
(0.16)\end{array}$ & $\begin{array}{l}54.1 \\
(4.37)\end{array}$ \\
\hline
\end{tabular}

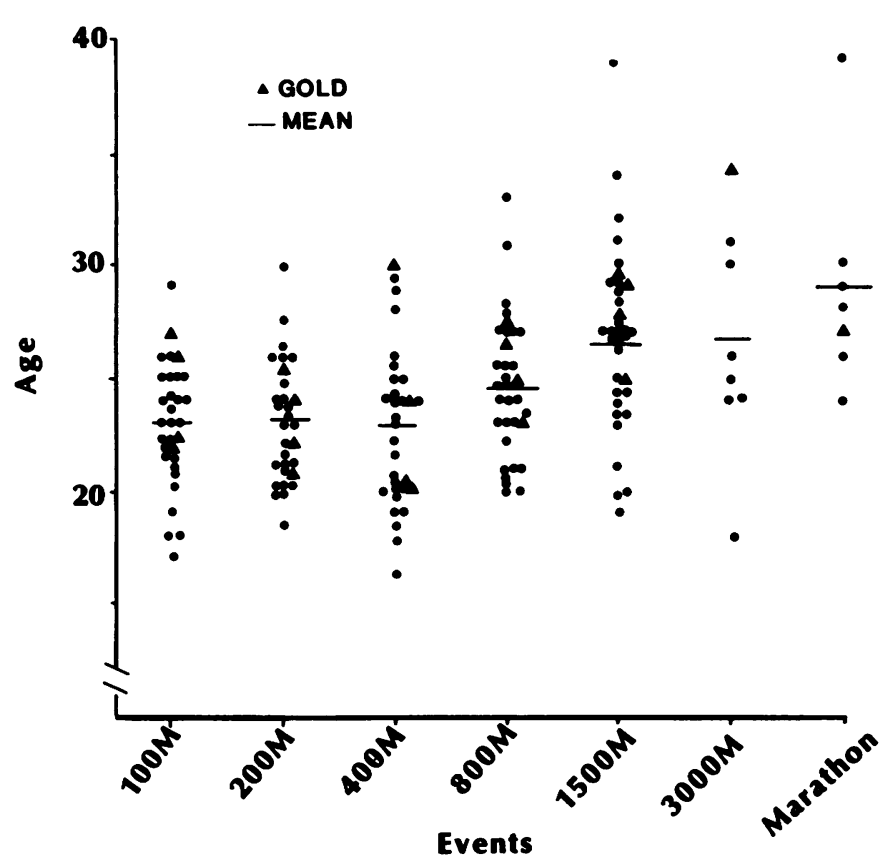

Fig. 1: Scatter diagram of age of female Olympic finalists from seven running events. In Figs. 1, 2 and 3 group means are represented by the horizontal lines; the triangles represent the gold medallists.

\section{Adjusted Weight at $165 \mathrm{~cm}$}

The mean adjusted weight at $165 \mathrm{~cm}$ increased progressively from $49.7 \mathrm{~kg}(110 \mathrm{lb})$ in marathon to $56.8 \mathrm{~kg}(125 \mathrm{lb})$ in $100 \mathrm{~m}$; the corresponding mean mass index ranged from 1.826 to $2.086 \mathrm{~g} / \mathrm{cm}^{2}$ (p value from Anova $<0.0001$ ). Thirteen pairwise comparisons were significantly different with

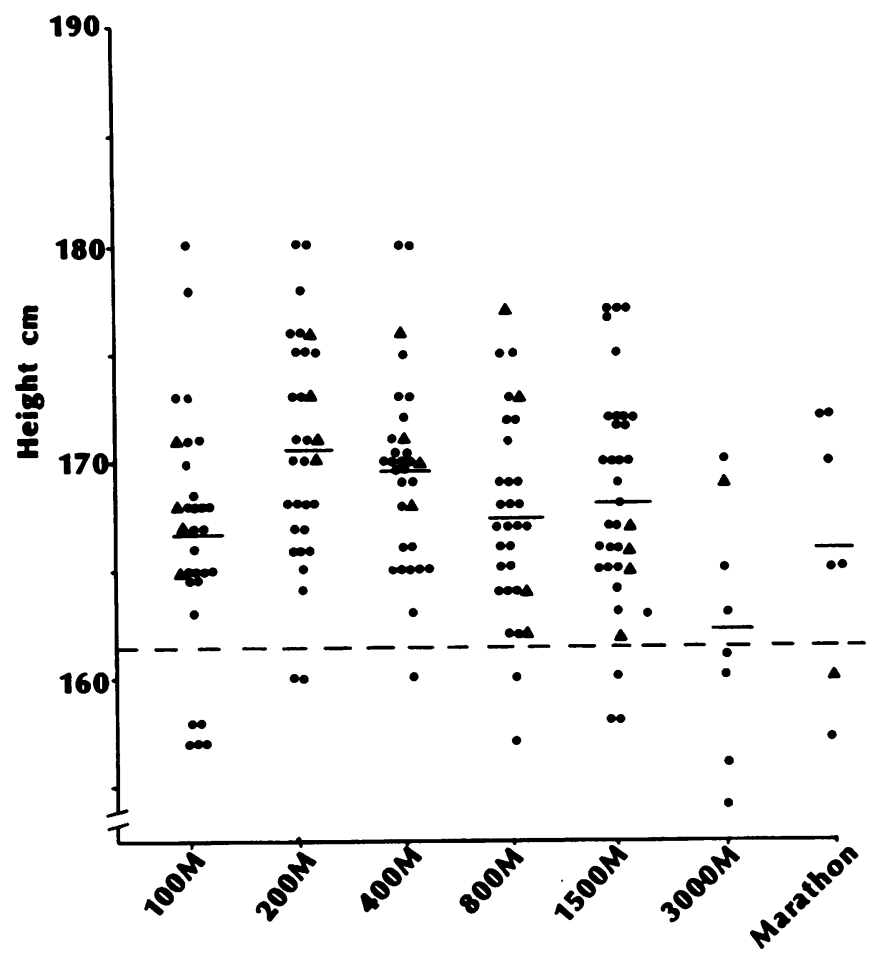

Events

Fig. 2: Scatter diagram of height of female Olympic finalists from seven running events. The horizontal line $(--)$ at $161.5 \mathrm{~cm}$ represents the average height of women aged 18-34 in Great Britain.

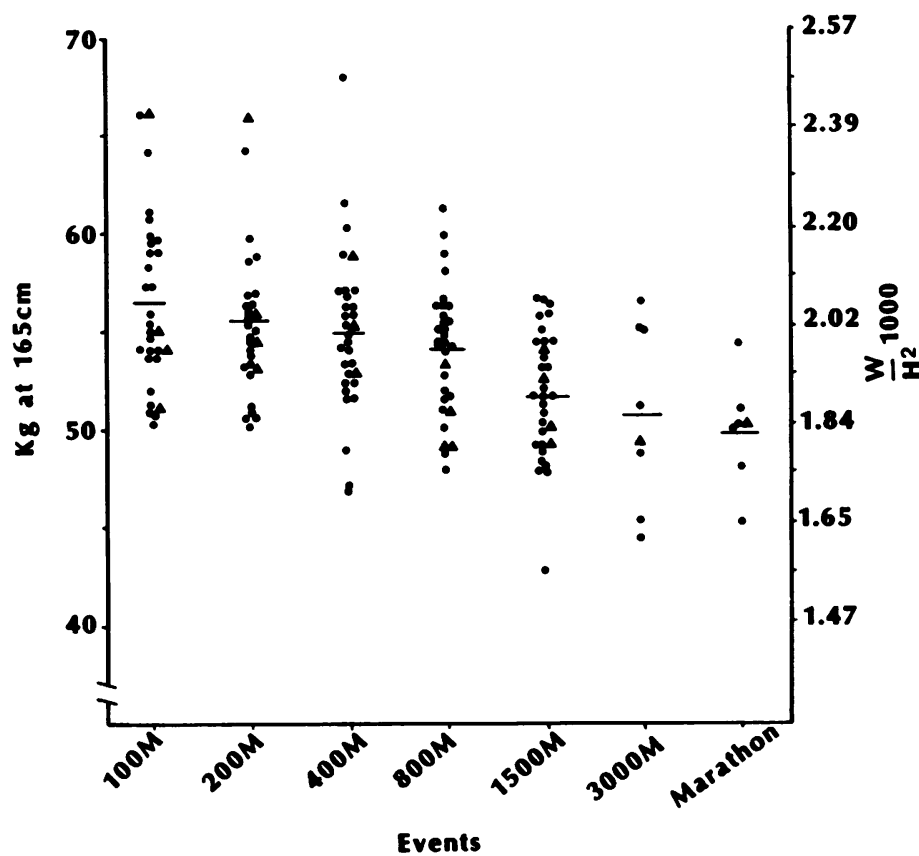

Fig. 3: Scatter diagram of adjusted woight and body mass index $\left(\mathrm{g} / \mathrm{cm}^{2}\right)$ of female Olympic finalists in seven running events.

Duncan's procedure; (i) each mean of the medium and long distance groups (1500 m, $3000 \mathrm{~m}$ and marathon) was significantly lighter than each of $100 \mathrm{~m}, 200 \mathrm{~m}, 400 \mathrm{~m}$, and 800 $\mathrm{m}$ (12 pairs), and (ii) $800 \mathrm{~m}$ was lighter than $100 \mathrm{~m}$ (1 pair). The adjusted weights of individuals ranged from $42.5 \mathrm{~kg}$ (94 (b) in $1500 \mathrm{~m}$ to $68.0 \mathrm{~kg}(150 \mathrm{lb})$ in $400 \mathrm{~m}$. For adjusted weight, multiple range testing does not do justice to the consistency of the pattern: Regardless of comparison a decreasing trend of weight with distance run as consistent as this (Fig. 3) occurs only once in 2520 times by chance and the data suggest rather a very steady, virtually linear trend. 


\section{DISCUSSION}

Height is highly correlated with various linear body dimensions and body weight with various breadths, girths and with skinfold measurements. Age, height and weight are good determinants of a number of aspects of physique (Khosla and McBroom, 1985). Women short distance runners are younger, taller and heavier for their height than medium and long distance runners. This trend was similar to that observed in men (Khosla, 1978).

The ages of gold medallists in the short and medium distance events $(100 \mathrm{~m}$ to $1500 \mathrm{~m})$ ranged from 20 to 30 years (Fig. 1). Several finalists older than 30 were observed in the medium and long distance events ( $800 \mathrm{~m}$ to marathon). Age is an important factor in the type of running event; sprinters may have to retire early but medium and long distance runners can continue well beyond their thirties. It is of interest to note that among the $3000 \mathrm{~m}$ finalists, whose ages ranged from 18 to 34 Zola Budd was the youngest whilst the gold medallist was the oldest (Fig. 1).

Height is an important factor in the type of running event. The gold medallists in all events other than the marathon were taller than the average height of women in Great Britain (Fig. 2). It is interesting to note that $100 \mathrm{~m}$ sprinters are significantly shorter than $200 \mathrm{~m}$ and $\mathbf{4 0 9 0} \mathrm{m}$ runners. It is probable that some relatively shorter medallists may derive some advantage with a quicker start (faster reaction) in the $100 \mathrm{~m}$ sprint. But the advantage of a faster reaction by a shorter sprinter is not enough in the $200 \mathrm{~m}$ and $400 \mathrm{~m}$ runs. Because of the height bias in the running events, competitors from Asian and Latin American countries (average height round $155 \mathrm{~cm}$ ) experience difficulty in competing in the running events. It is of interest to record that even Japan did not participate in any of the female running events excepting the marathon in the Los Angeles Olympics.

Height for height the finalists in the sprinting events are heavier than medium and long distance runners. Adjusting for height the endurance runners were lighter than sprinters by about $6 \mathrm{~kg}$. In terms of height, the silver medallist sprinter at Los Angeles $(158 \mathrm{~cm})$ was comparable to the bronze medallist marathon runner $(157 \mathrm{~cm})$. But in terms of body weight the sprinter was $9.5 \mathrm{~kg}(21 \mathrm{lb})$ heavier $(55.5 \mathrm{~kg}$ vs $46.0 \mathrm{~kg}$ ). Much of the excess weight in the sprinting events is probably composed of muscle mass on a medium framed body. It appears that the optimum weight for height standard is related to frame size; obviously at a given height, a small framed body with a specified weight considered optimum for a medium frame will become a burden to the sprinter.

In the newly introduced $3000 \mathrm{~m}$ run, Zola Budd was the lightest (adjusted weight $\mathbf{4 4} \mathrm{kg}$ ) in the range of weights 44 to $56 \mathrm{~kg}$ (Fig. 3). She was $6.8 \mathrm{~kg}$ lighter than the average of the three medallists, and $3.7 \mathrm{~kg}$ lighter than Mary Decker. Many other factors of physiological and psychological nature are of importance in the making of finalists. But very little information is documented on them besides age, height and weight. Low heart rate (less than $50 \mathrm{bpm}$ ) is an important variable in successful marathon runners (Khosla and Campbell, 1982). In general possession of optimum standards on age, height and weight are not sufficient by themselves, but they are prerequisites in the selection and training of potential champions in international competitions, and in the national competitions of western countries (Khosla and McBroom, 1984).

\section{ACKNOWLEDGEMENTS}

I am thankful to Mr. S. J. Pritchard for his efforts in getting the data on athletes from Moscow. Thanks are due to Mrs. V. C. McBroom for her help with the computer programs, to Mrs. Pamela Heard for word processing and to the Department of Medicial Illustration for the Figs. I am indebted to Dr. E. C. Coles for his moral support and encouragement.

\section{References}

Khosla, T., 1978 "Standards on age, height and weight in Olympic running events for men". Brit.J.Sports Med. 12 (2): 97-101.

Khosla, T. and Campbell, H., 1982 "Resting pulse rate in marathon runners". Br.Med.J. 284: 1444.

Khosla, T., 1984 "Physique of female swimmers and divers from the 1976 Montreal Olympics". JAMA 252 (4): 536-537.

Khosla, T. and McBroom, V. C., 1984 "Physique of female Olympic finalists". Published by Department of Medical Computing and Statistics, Welsh National School of Medicine, Heath Park, CARDIFF, CF4 4XN UK

Khosla, T. and McBroom, V. C., 1985 "Age, height and weight of female Olympic finalists". Brit.J.Sports Med. 19: 96-99.

Knight, I., 1984 "The heights and weights of adults in Great Britain". HMSO London.

Simmons, R., 1984. Editor, Athletics Coch Vol. 18, No. 4, London: 18-44.

The article printed above is published posthumously, as Dr. Khosla, we were distressed to hear, died suddenly in India while on a holiday with the object of finding and purchasing a home for his imminent retirement. Triloke Khosla settled in Wales many years ago, as a Medical Statistician to the Welsh National School of Medicine. Like many statisticians, he took a keen interest in the statistics of sport, and soon realised, by analysis of the physiques of medallists that body, build, especially height and weight were most important factors for success. After joining the British Association of Sport and Medicine in 1970, he delivered a paper at one of our meetings but put the case for height and/or weight categories in track and field athletes on similar lines to weight categories in boxing, wrestling and weight-lifting. As each Olympiad passed, he was able to gain more evidence to support his view and several articles were published in the British Journal of Sports Medicine, letters and articles in the British Medical Journal, and a book that was published by the National University of Wales.

It is regrettable that his views have not been given wider acceptance, but as he has said and written, "Sport for All" really means "Sport for Tall". We shall miss him at our meetings, and a gap will be left in the sporting and medical literature by someone who at least did something with the information collected at major sporting events.

We extend our deepest sympathy to his widow and his family. 